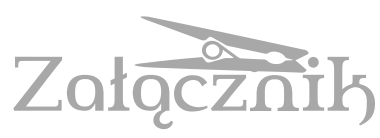

\title{
CZYM JEST POLSKI DESIGN?
}

ANNA KOSTRZYŃSKA-MıŁOSZ

Instytut Sztuki Polskiej Akademii Nauk w Warszawie Institute of Art, Polish Academy of Sciences in Warsaw anna.kostrzynska-milosz@ispan.pl

Na pytanie, czym jest polski design, składają się dwa zagadnienia; pierwsze - co rozumiemy przez określenie „design”, i drugie - które z projektów możemy nazwać polskimi?

A więc czym jest design? Choć to bardzo złożone zagadnienie, na potrzeby tych rozważań należy ustalić zwięzłe kryteria wyznaczające jego granice. Design to wypadkowa trzech elementów: doznań a rtystycznych, możliwości technicznych i potrzeb społeczno-kulturowych. Jak pisze Peter Bürger „design to sztuka, która zatraciła się w praktyce życiowej, a tracąc do niej dystans, przestała funkcjonować stricte jako sztuka, stając się nowym obszarem poszukiwań i eksperymentów"'. Zdaniem Alicji Głutkowskiej-Polniak, rozważającej design w kontekście estetyki, design to „sztuka przysposobiona do życia”" . Bardzo istotnym elementem designu jest możliwość wielokrotnego powielania, a więc tworzenia wzoru, który musi zakładać swoje zwielokrotnienie. Czy jest to jednak warunek dostateczny? Jeśli to twierdzenie byłoby prawdziwe, wszelkie wzorniki, tworzące przecież jakiś szablon, powinny być zaliczane do historii designu, a jednak tak nie jest.

Już w drugiej połowie XVII wieku Jean-Baptiste Colbert, minister finansów na dworze Ludwika XIV, sprawił, że wśród królewskich stolarzy powstała grupa ebenistów, którzy tworzyli wzory ornamentów (np. Jean Bérain) czy projektowali całe meble (André-Charles Boulle). Pierwsza połowa XVIII wieku w Anglii obfitowała w wydane i licznie wznawiane

${ }^{1}$ P. Bürger, Teoria awangardy, tłum. J. Kita-Huber, red. K. Wilkoszewska, Kraków 2006, s. 61.

2 A. Głutkowska-Polniak, Dizajn w kontekście estetyki: jego początki, przeobrażenia i konotacje, Katowice 2017, s. 13. 
wzorniki. Najbardziej znane to: The Gentleman and Cabinet Maker's Director (1754) Thomasa Chippendale'a, Works in Architecture of Robert and James Adam (1773) Roberta Adama, The Cabinet Maker and Upholsterers Guide (1788) George'a Hepplewhite'a, a także The Cabinet Maker's and Upholsterer's Drawing Book (1791) i The Cabinet Dictionary (1803) - obydwa autorstwa Thomasa Sheratona. Ten ostatni zawierał nie tylko rysunki przedmiotów, ale również instrukcję dotyczącą wytwarzania mebli. Ich twórców nie określa się jednak jako designerów, choć projekty były realizowane w większej liczbie egzemplarzy, to wytwarzano je w sposób rzemieślniczy.

Wydaje się więc, że zasadniczym elementem, który pozwala posługiwać się pojęciem „design”, jest maszyna - możliwość mechanicznego powielania przy jej użyciu. Przy czym należy zaznaczyć, że ważny jest sam zamiar maszynowego powielania, nieważna zaś liczba wytworzonych przedmiotów. Można zatem uznać, że design narodził się wraz z rozwojem przemysłu w drugiej połowie XIX wieku, choć wówczas był określany jako przemysł artystyczny ${ }^{3}$. Na przełomie XIX i XX wieku zaczęto używać nazw „sztuka użytkowa”, „sztuka stosowana” do przemysłu, by dopiero po II wojnie światowej wprowadzić określenie „wzornictwo przemysłowe”, stosowane obecnie wymiennie z terminem „design"4.

W polskiej literaturze dotyczącej historii designu rozważania na ogół zaczynają się od stylu zakopiańskiego. Styl zakopiański, rozumiany jako lansowanie pewnych nowych tendencji, tworzenie wzorów polskiego stylu, z pewnością odpowiada kategorii narodowej, ale nie był tworzony z myślą o produkcji maszynowej. Niewątpliwie to bardzo znacząca idea, ale czy może być uznawana za początki polskiego designu? Refleksje dotyczące stylu zakopiańskiego prowadzą do drugiej części zagadnienia: co możemy uznać za dorobek p ols ki e go designu? Ostatecznie - do 1918 roku trudno zakreślić wyraźne granice tego, co polskie.

3 K. Szczepkowska-Naliwajek, Dzieje badań nad dawnym rzemiosłem artystycznym w Polsce 1800-1939, Toruń 2005, s. 13. Autorka podaje szereg opracowań z epoki, w których występuje termin „przemysł artystyczny”.

${ }^{4}$ Ibidem, s. 15-16. 
Można postawić tezę, że na terenach Polski ${ }^{5}$ zalążkiem nowego spojrzenia na sztukę użytkową, zastosowaną do przemysłu, były muzea przemysłowe ${ }^{6}$, zbierające dobre wzory i prowadzące szeroką działalność dydaktyczną. Najstarsze z nich, Muzeum Techniczno-Przemysłowe, założono w Krakowie w 1868 roku. Jego inicjatorem i fundatorem był Adrian Baraniecki, którego inspirowały idee Williama Morrisa o odnowie rzemiosła i tworzeniu nowych wzorów. Baraniecki, budując zbiór, chciał pokazać, że przedmioty wytwarzane przemysłowo mogą być piękne, ale były to obiekty zakupione w Anglii i Francji. To one miały prezentować nowoczesne tendencje panujące w tej dziedzinie w całej Europie.

Kolejnymi znaczącymi ośrodkami propagującymi nowe wzory były: lwowskie Miejskie Muzeum Artystyczno-Przemysłowe (1874) ${ }^{7}$, a także warszawskie Muzeum Przemysłu i Rolnictwa $(1875)^{8}$ oraz Muzeum Rzemiosł

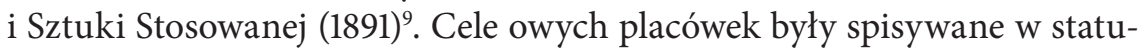
tach, przykładowo: w statucie Muzeum Przemysłu i Rolnictwa zaznaczono w $\$ 1$, że chodzi o: „danie przemysłowcom, rzemieślnikom i gospodarzom wiejskim, możność poglądowego studjowania przedmiotów, dotyczących ich zawodowych zatrudnień, tudzież obznajmiania się z ulepszonemi sposobami produkcyi i badania technicznego"10.

Dużą rolę w propagowaniu nowych form miały również wystawy. Pierwsza ważna ekspozycja odbyła się w 1821 roku. Zgodnie z wcześniejszą

${ }^{5}$ Ponieważ Polska jako państwo w drugiej połowie XIX wieku nie istniała, posługuję się terminem „tereny Polski”, mając na myśli obszar, na którym przeważała ludność polskojęzyczna.

${ }^{6}$ K. Szczepkowska-Naliwajek, op. cit., s. 125-129.

7 E. Chwalewik, Zbiory polskie. Archiwa, biblioteki, gabinety, galerie, muzea i inne zbiory pamiątek przeszłości w ojczyźnie i na obczyźnie w porządku alfabetycznym według miejscowości ułożone, Warszawa 1926-1927.

8 A. Tołysz, Muzeum Przemystu i Rolnictwa w Warszawie. Jedno muzeum wiele instytucji, http://muzeumpamieci.umk.pl/?p=5077 [dostęp: 10.04.2019].

9 M. Dłutek, Warszawskie Muzeum Rzemiosł i Sztuki Stosowanej. Rys historyczny, [w:] W kręgu sztuki przedmiotów. Studia ofiarowane Profesor Irenie Huml przez przyjaciół, kolegów i uczniów, red. M. Dłutek, A. Kostrzyńska-Miłosz, Warszawa 2011, s. 275-289.

10 A. Tołysz, op. cit., s. 1. 
o trzy lata ustawą „O organizowaniu w Warszawie krajowych wystaw wytwórczości i sztuk pięknych” musiano wystawić „wyborniejsze dzieła przemysłu krajowego"11, z tym że za przemysł uważano także rękodzieła i wystawę sztuk pięknych. W zamyśle organizatorów ekspozycja miała być świadectwem postępu cywilizacyjnego we wszystkich dziedzinach, ale: „Tylko mieszkańcy kraju osiedli do tych popisów będą przypuszczonemi. Komisarze do tego przeznaczeni przed wystawieniem przedmiotów na widok publiczny rozpoznają dowody, czyli są rzeczywiście owocem przemysłu krajowego..."12. Na wystawie tej, obok sieczkarni żelaznej i odlewów gipsowych Wenus czy Apolla Belwederskiego, znalazły się: talerz z Ćmielowa, półmisek szklany rżnięty, a także wyroby biżuteryjne Michała Schwartza Jubilera w Warszawie ${ }^{13}$.

Interesująca ekspozycja, zgromadzona pod hasłem: „Wystawa dzieł sztuki stosowanej”, odbyła się w Pałacu Brühla w Warszawie w 1881 roku. Choć tytuł wiąże się z omawianym tematem, zgromadzono tu wiele bardzo różnych przedmiotów. Katalog wystawy zwierał szereg działów: ceramika polska, ceramika zagraniczna, porcelana chińska, porcelana saska, porcelana berlińska, wiedeńska, szkło ${ }^{14}$, brązy, wyroby złotnicze, biżuteria, zegarki, zastawy i naczynia stołowe w srebrze, puchary, dzbany, kubki, tace i misy, kandelabry, wyroby z kości, rogu, drewna, miedzi, mosiądzu, cyny, marmuru, tkaniny, hafty, koronki, ubiory, przybory wojenne. Katalog obejmował łącznie 1570 przedmiotów, były to jednak obiekty o proweniencji historycznej, a wyrobów określanych jako „tegoczesne” opisano zaledwie dziesięćc ${ }^{15}$. Jedynie między kartami wyliczającymi eksponaty pojawiały się całostronicowe reklamy pokazujące dorobek ówczesnego przemysłu.

${ }^{11}$ A. Drexler, Wystawy wytwórczości Królestwa Polskiego, Warszawa 1999, s. 39.

12 Ibidem, s. 108.

13 Ibidem, s. 194-197.

14 Przedmioty opatrywano różnymi, często zabawnymi z dzisiejszego punktu widzenia podpisami, np. „dzban szklany emaliowany znaleziony na dnie Sanu wyrób wenecki średniowieczny własność Zygmunta Glogera"; Katalog wystawy dzieł sztuki stosowanej do przemystu urządzonej staraniem Komitetu Muzeum Przemysłu i Rolnictwa w Warszawie w Pałacu Brühlowskim otwartej 14 czerwca 1881, Warszawa 1881.

15 Ibidem. 
Ważną, ze względu na wyodrębnienie działu „Okazy sztuki nowożytnej, stosowanej do przemysłu”, była późniejsza ekspozycja, urządzona w Muzeum Przemysłu i Rolnictwa w 1889 roku. Przedmioty wytwarzane w latach 80. XIX wieku wystawiono tu obok obiektów zabytkowych: opraw książkowych, dawnych ubiorów, uzbrojenia, numizmatyki, porcelany, fajansu, zegarów ${ }^{16}$.

W początkowym okresie rozwoju polskiego designu istotną rolę odegrało Towarzystwo Polska Sztuka Stosowana założone w 1901 roku. Jak wskazuje Maria Dłutek:

Nowe było tu rozumienie wzorów szeroko propagowanych przez gromadzenie odpowiednich zbiorów, organizowanie tematycznych wystaw, konkursów, a także przez dobór artykułów i ilustracji w wydawanym przez Towarzystwo piśmie „Materiały Polskiej Sztuki Stosowanej”, a od 1906 „Sztuka Stosowana”"17.

W ten sposób powstały specyficzne wzorniki dla anonimowych odbiorców, którym starano się wytłumaczyć równocześnie pochodzenie, istotę i sens istnienia wzoru. Artyści, projektujący w ramach Towarzystwa owe „nowe wzory” - tacy jak Józef Czajkowski, Karol Frycz, Józef Mehoffer, Ferdynand Ruszczyc, Jan Szczepkowski, Karol Tichy, Edward Trojanowski i Stanisław Wyspiański - realizowali pojedyncze obiekty, które miały inspirować. Byli to na ogół wykształceni malarze, rzadziej rzeźbiarze, nie zawsze rozumiejący wymogi funkcjonalności czy ergonomii; oni raczej „myśleli formą". Ofiarą takiego pojmowania designu padł Tadeusz Boy-Żeleński, któremu na przełomie lat 1904 i 1905 Stanisław Wyspiański projektował wnętrza mieszkania przy Karmelickiej 6 w Krakowie ${ }^{18}$. Boy wspominał:

Wymiary mebli wynikłe [...] z zasady geometrycznej dawały różne niespodzianki. Stoliki nocne były na przykład tak olbrzymie, że blat ich sięgał do piersi człowieka; zarazem sprzeciwiały się całkowicie celom użytkowym:

${ }^{16}$ K. Szczepkowska-Naliwajek, op. cit., 127.

17 M. Dłutek, Od wzoru do wzornictwa, [w:] Wzornictwo w Polsce, red. M. Kulik, Warszawa 1988, s. 7.

18 Reprodukowane i omówione w katalogu wystawy: Wyspiański. Katalog wystawy dzieł ze zbiorów Muzeum Narodowego w Krakowie, red. D. Godyń, M. Laskowska, Kraków 2017, s. 419-424. 
ani spojrzeć na zegarek, ani wypić herbatę w łóżku, nic! Olbrzymie fotele w sypialni miały siedzenie o jakieś $10 \mathrm{~cm}$ wyższe od normalnych, stolik zaś, wskutek zasady, że ma być równej wysokości z poręczami, był tak niski, że o kant uderzało się kolanami, których nie było sposobu podziać. Bardzo ciężkie, a szalenie niewygodne krzesełka były istnym narzędziem tortur. [...] „Cierp i czuwaj” - zdawał się mówić każdy mebel ${ }^{19}$.

Na początku XX wieku powstało wiele organizacji artystycznych, które miały odnowić wzornictwo na terenach Polski; były to m.in.: Polska Sztuka Podhalańska (Zakopane 1909), Stowarzyszenie „Kilim” (Zakopane 1910), Towarzystwo Polskiej Sztuki Stosowanej „Zespół” (Lwów 1911), Związek Architektura, Rzeźba, Malarstwo i Rzemiosło (Kraków 1911) ${ }^{20}$. Pośród nich najbardziej znaczące, odwołujące się do idei Wiener Werkstätte (1903), były Warsztaty Krakowskie (1913). Kontynuowały one w pewnym sensie działalność Towarzystwa Polskiej Sztuki Stosowanej. Artyści do nich należący - m.in. Antoni Buszek, Józef Czajkowski, Karol Homolacs, Stanisław Getter, Wojciech Jastrzębowski, Włodzimierz Konieczny, Henryk Kunzek, Bonawentura Lenart, Kazimierz Młodzianowski, Zofia Stryjeńska, Karol Stryjeński, Zofia Szydłowska, Jerzy Warchałowski - prowadzili szereg kursów i pracowni przy Muzeum Techniczno-Przemysłowym w Krakowie ${ }^{21}$. Tym, co wyróżniało Warsztaty, była „celowość przedmiotów”, rozumiana jako funkcjonalność i znajomość właściwości materiałów, co mogło być wynikiem włączenia na równych prawach do stowarzyszenia doświadczonych rzemieślników. W Warsztatach Krakowskich próbowano wprawdzie pokazywać i wprowadzać nowe wzory, ale były to działania na niewielką skalę i wiązały się raczej z odnową rzemiosła artystycznego niż sztuki zastosowanej do przemysłu.

Powstanie Bauhausu w 1919 roku zwróciło uwagę polskich artystów na nowoczesność i standaryzację wzorów. Jednak w formach przedmiotów wytwarzanych w naszym kraju można w tym okresie wyraźnie zauważyć,

19 T. Boy-Żeleński, Historia pewnych mebli, [w:] idem, Reflektorem w mrok. Wybór publicystyki, wyb., wstęp i oprac. A.Z. Makowiecki, Warszawa 1985, s. 146.

20 I. Huml, Polska sztuka stosowana XX wieku, Warszawa 1978, s. 44-48.

${ }^{21}$ Ibidem, s. 49-52; Warsztaty Krakowskie 1913-1926, red. I. Dziedzic, Kraków 2009. 
obok aspektów artystycznego i technicznego, wpływ trzeciego czynnika składającego się na określenie „design”, mianowicie: społeczno-kulturowego.

Wraz z odzyskaniem niepodległości pojawiła się potrzeba podkreślania narodowego charakteru sztuki. Szczególnym wyrazem tych tendencji była ekspozycja polska na Międzynarodowej Wystawie w Paryżu w 1925 roku i późniejsza działalność Spółdzielni Artystów Plastyków „Ład”. Zaczęto projektować przedmioty, które miały „nutę ludowości”, doceniono także potrzeby przemysłu - tu istotną rolę powierzono szkolnictwu wyższemu i półwyższemu. Powstały wówczas wydziały sztuki stosowanej w Szkole Sztuk Pięknych (od 1932 r. - Akademii) w Warszawie i na Uniwersytecie w Wilnie, zorganizowano Szkoły Sztuk Zdobniczych w Warszawie, Krakowie, Poznaniu oraz Lwowie, a także Państwową Szkołę Przemysłową w Bydgoszczy. Nawet na Politechnice Warszawskiej, przy Wydziale Architektury, powstało w 1936 roku Studium Wnętrz i Sprzętu, gdzie organizowano warsztaty ceramiczne, szklarskie i stolarskie ${ }^{22}$. Część z tych uczelni pozostała jednak w kręgu tworzenia wzorów wykonywanych rzemieślniczo.

W okresie międzywojennym wyróżniała się Szkoła Sztuk Zdobniczych i Przemysłu Artystycznego w Poznaniu, współpracująca z przemysłem i projektującą dlań wzory. Studenci tej uczelni odbywali praktyki w fabrykach mebli i ceramiki, toteż dokładnie poznawali idee produkcji i specyficzne potrzeby przemysłu.

W latach trzydziestych rodzi się pewien rozdźwięk między tworzeniem nowego, charakterystycznego dla polskiego designu stylu, a powstawaniem wzorów w nurcie nowoczesnym, które można powielać przemysłowo. Nurt związany z poszukiwaniem narodowego wyrazu w sztuce użytkowej, zapoczątkowany w latach 20., którego przedstawiciele odnieśli międzynarodowy sukces na wystawie paryskiej w 1925 roku, a kontynuowany przez „, Ład”, był związany raczej z rzemieślniczym wytwarzaniem przedmiotów. Nie spełnia zatem podstawowego założenia designu: projektowania przedmiotu

${ }_{22}$ Poznańska zdobnicza: historia Państwowej Szkoły Sztuk Zdobniczych i Przemystu Artystycznego w Poznaniu w latach 1919-1939, oprac. J. Mulczyński, oprac. graf. M. Pawłowski, Poznań 2009; Szkoły przemysłowe we Lwowie w XIX i XX w., cz. 1: Miejska Szkoła Przemysłowa i Handlowa, Państwowa Szkoła dla Przemysłu Artystycznego, Państwowa Szkoła Przemysłowa, oprac. J. Kowalczuk, Kraków 2011. 


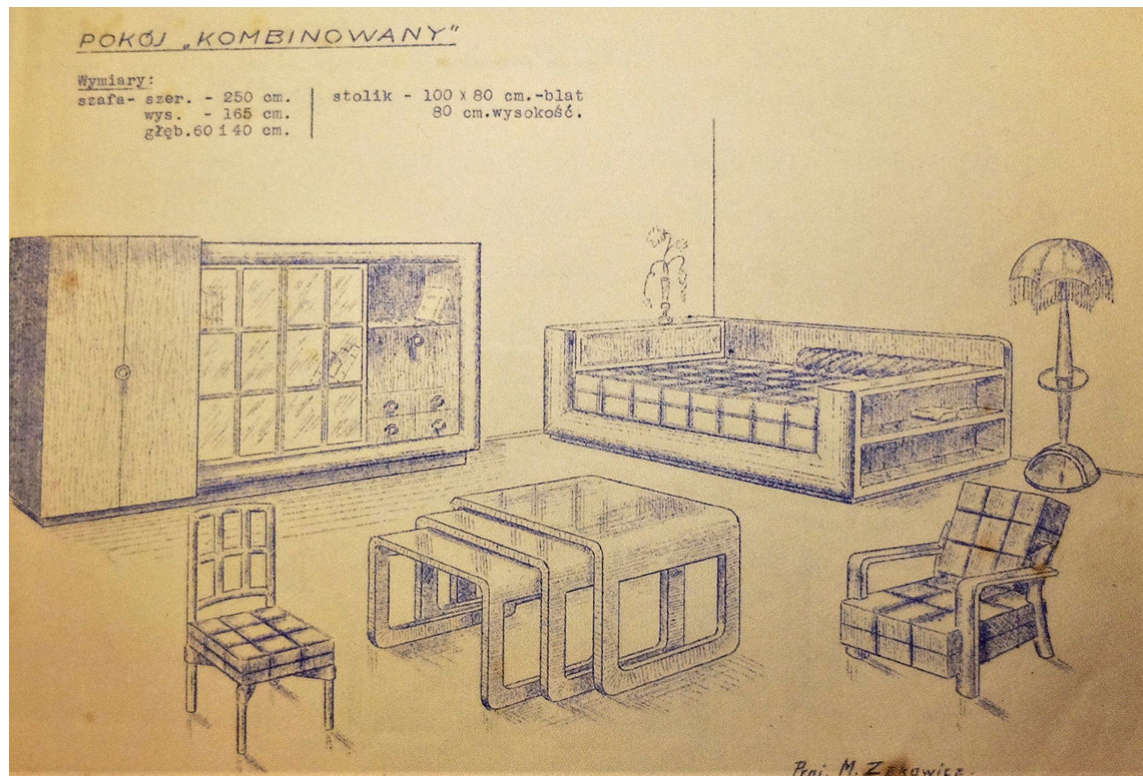

Il. 1. Pokój kombinowany; projekt inspirowany nowoczesnymi trendami; lata 30.

z zamiarem wielokrotnego maszynowego powielania (choć twórcy „Ładu” mieli zamiar wprowadzić produkcję na większą skalę). Ten podział w swoich rozważaniach bardzo wyraźnie zaznaczył Jan Goliński, pisząc w 1936 roku: „Pod wpływem pobudek myślowych techniki, człowiek usiłuje niszczy jedne formy materji, aby uzyskać nowe, jemu przydatne, - to rzemiosło. Jeśli zachodzi potrzeba powielania wyników rzemiosła, tworzy się przemysł"23.

Zatem dopiero drugi nurt poszukiwania nowoczesności, standaryzacja projektu, jest działaniem, które skłonna byłabym nazwać „designem”.

Ten typ myślenia o produkcji, wywodzący się z kręgów europejskiej awangardy chcącej „zmaszynizować świat”, pozostał w Polsce okresu międzywojennego w sferze teorii głoszonych przez ugrupowania artystyczne Blok i Praesens, kultywujące idee Bauhausu. Ich echa znajdujemy w ówczesnych projektach środowiska architektów poszukujących nowych form. Bardzo wyraźnie nawiązywano do tych zagadnień w kręgach Studium Wnętrz

${ }^{23}$ J. Goliński, Długa jeszcze droga do wnętrz jutra, „Architektura i Budownictwo” 1936, nr 3, s. 78. 
i Sprzętu. Stefan Sienicki, założyciel Studium, uważał, że należy stworzyć koncepcję powszechnie dostępnych mebli i wypracować wzorce projektowe z przeznaczeniem dla rzemiosła i przemysłu ${ }^{24}$, co okazało się nie takie znowu proste. Swoje poglądy formułował, pisząc o normach w meblarstwie m.in. w „Arkadach”25. Jeden z członków Studium Wnętrz i Sprzętu, Kazimierz Prószyński, pisał w 1933 roku w artykule zatytułowanym Standaryzacja, iż: „Można znaleźć wielu doskonałych wykonawców, projektodawców można policzyć na palcach"26. Chciano stworzyć proste i łatwe do powielania wzory, które będą jednocześnie funkcjonalne, choć wspominano w prasie, że poszukiwania te nie są niczym nowym i mają swoje źródła w europejskiej teorii projektowania (il. 1-2).

Po wojnie, w latach 60. XX wieku, pojawia się podobne rozdwojenie kierunków rozwoju designu: z jednej strony nawiązywanie do sztuki ludowej,

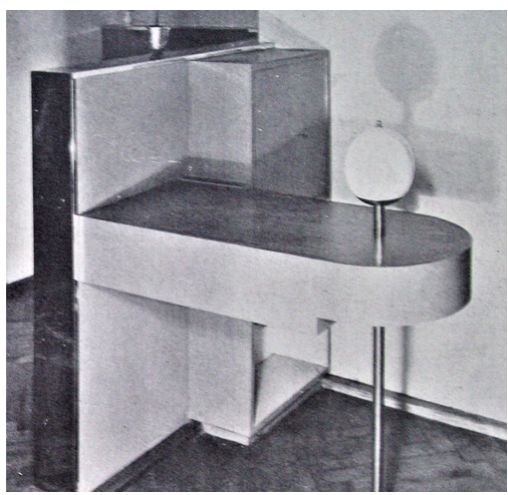

Il. 2. Stefan Sienicki, Kazimierz Prószyński, projekt kontuaru; lata 30.

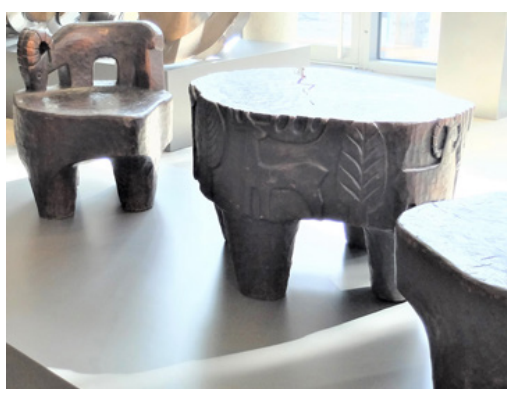

Il. 3. Władysław Trojan, zestaw mebli; powojenne inspiracje sztuka ludowa (wystawa przedaukcyjna Desa-Unicum) z drugiej - fascynacja nowoczesnymi tendencjami (il. 3-5). Na dwóch skrajnych pozycjach stoją wówczas Cepelia oraz Instytut Wzornictwa Przemysłowego. Cepelia (Centrala Przemysłu Ludowego i Artystycznego) powstała w 1949 roku na wniosek Ministerstwa

${ }^{24}$ T. Mikołajczak, Żaluzjowe meble Władysława Winczego, „Quart” 2017, nr 3, s. 63.

25 Zob. S. Sienicki, Normy w meblarstwie, "Arkady” 1935, nr 2, s. 110-111; idem, Zagadnienie normalizacji w meblarstwie, [w:] Meble wnętrz mieszkalnych, red. M. J. Leykam, Warszawa 1937, s. 13-20.

${ }^{26}$ K. Prószyński, Standard, „Wnętrze” 1933, nr 4, s. 62. 


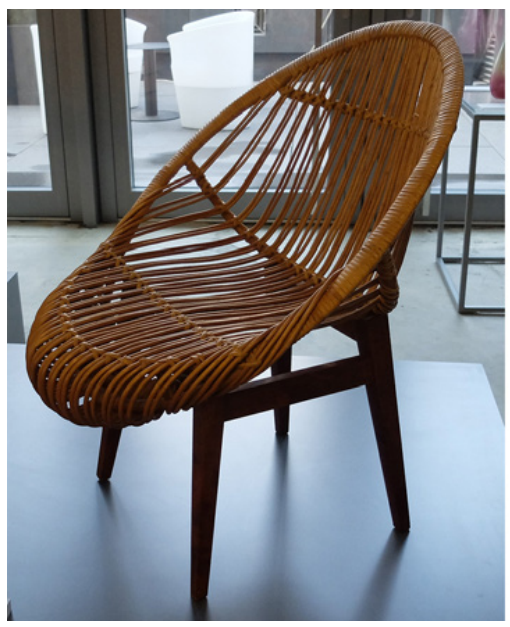

Il. 4. Zygmunt Majchrzak, fotel; wiklina materiat nawiązujący do rodzimości; lata 60.

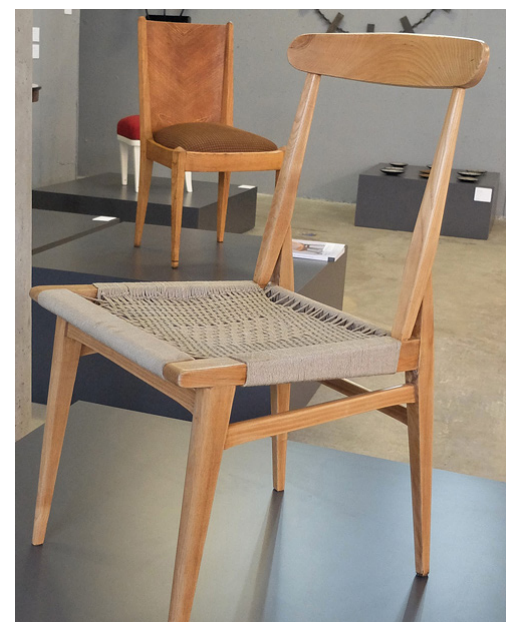

Il. 5. Marian Sigmund, krzesto; zastosowanie naturalnego koloru drewna i wyplotu siedziska ze sznurka nawiazuje do haset Spółdzielni „Еad”; lata 60.

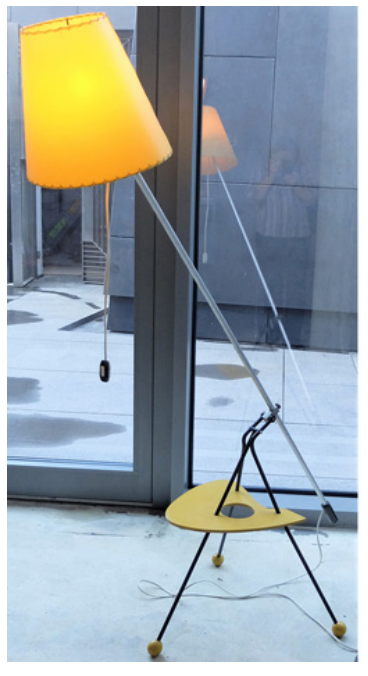

Il. 6. Lampa; design inspirowany nowoczesnością; lata 60 .
Kultury i Sztuki oraz Biura Nadzoru Estetyki Produkcji. Jej zadaniem było „roztoczenie opieki państwa nad wytwórczością ludową”. W praktyce zrzeszała wiele mniejszych i większych wytwórni, których projekty nie zawsze nawiązywały do sztuki ludowej. W drugim roku działalności Cepelia obejmowała swą kuratelą dwieście osiem spółdzielni rękodzieła ludowego i artystycznego (m.in.: „Ład”, „Koronka”, „Wanda”, „Pilsko”, „Sztuka Łowicka”, „Rękodzieło Artystyczne”, „Region”, „Podhalańska”, „Imago Artis”) oraz sto pięć zakładów przemysłu artystycznego. Przynależność do większej organizacji pomagała wytwórniom łatwiej zdobyć materiały potrzebne do produkcji. Co ciekawe, cepeliowska ludowość była akceptowana przez warstwy inteligenckie. Środowisko robotnicze, do którego należało wiele 
osób przyjezdnych, nie ceniło z kolei tego rodzaju stylistyki.

W Instytucie Wzornictwa Przemysłowego - zorganizowanym w 1950 roku, a wywodzącym się z powstałego w 1946 roku Wydziału Wytwórczości, przekształconego w latach 1947-1950 na Biuro Nadzoru i Estetyki Produkcji - stawiano na nowoczesność (il. 6-8). Jego

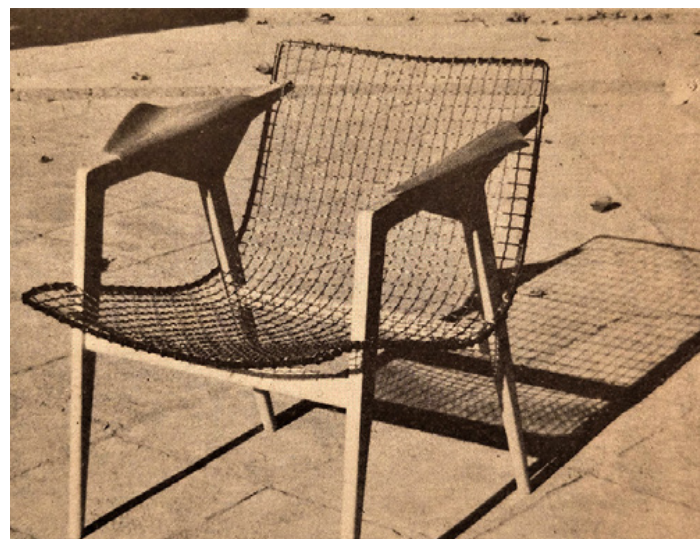

Il. 7. Czesław Knothe, fotel z siatki metalowej; prawdopodobnie inspiracja meblami Harrego Bertoi hasło: „kultura i sztuka na co dzień i dla wszystkich”, głoszone przez inicjatorkę Instytutu, Wandę Telakowską, miało inspirować do tworzenia projektów przedmiotów funkcjonalnych i zgodnych z panującą ówcześnie modą. Szczególnie widoczne jest to w latach 60., kiedy artyści mieli łatwiejszy dostęp do zachodnioeuropejskich czasopism, a także pojawiła się możliwość wyjazdów zagranicznych. Chodziło o podnoszenie jakości wyrobów przy abstrahowaniu od wymogów gospodarki rynkowej - przedmioty nie miały przyciągać nabywców, miały jedynie pokazywać nowoczesność. Wiele z nich nie weszło do masowej produkcji.

Czym więc jest i co charakteryzuje polski design? Jeśli projektanci inspirowali się tradycją - najczęściej elementami sztuki ludowej - to rzeczywiście tworzyli przedmioty o cechach niespotykanych w żadnym innym kraju, jednak były to wyroby produkowane może nie rzemieślniczo, ale w krótkich seriach i w małych spółdzielniach, a zatem pozostawały w pewnym stopniu indywidualne. Jeśli natomiast designerzy inspirowali się kierunkami awangardowymi czy nowoczesnymi, trudno je nazwać polskimi, bowiem przy ich produkcji posiłkowano się ideami płynącymi z zagranicy, a właśnie te wyroby w swoich założeniach miały być produkowane przemysłowo.

Można zatem uznać, że polski design to zderzenie tradycji z nowoczesnością, chęci pozostania w kręgu kultury narodowej i podążania za światowymi tendencjami. 


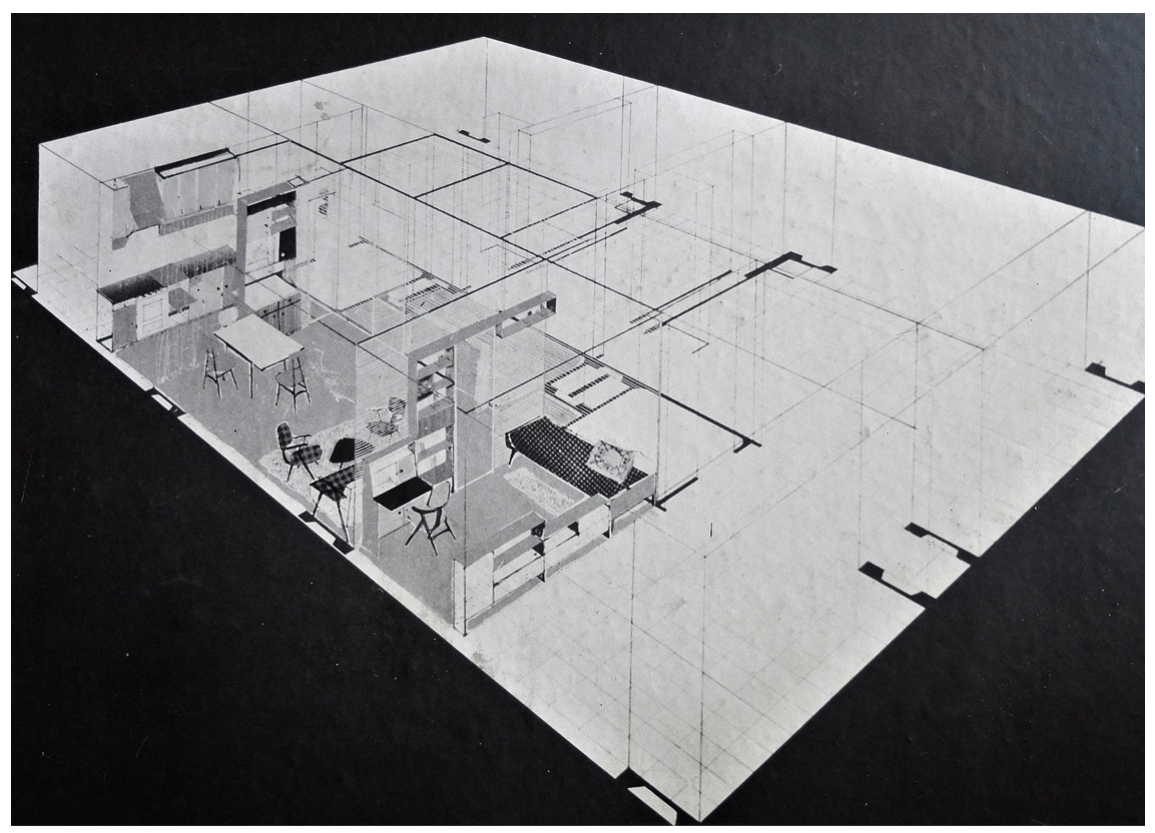

Il. 8. Marian Sigmund, projekt nowoczesnego mieszkania dla dwóch osób; lata 60.

\section{Bibliografia}

Tadeusz Boy-Żeleński, Reflektorem w mrok. Wybór publicystyki, wyb., wstęp i oprac. A.Z. Makowiecki, Państwowy Instytut Wydawniczy, Warszawa 1985.

Piotr Bürger, Teoria awangardy, tłum. J. Kita-Huber, red. K. Wilkoszewska, TAiWPN Uniwersitas, Kraków [cop. 2006].

Maria Dłutek, Warszawskie Muzeum Rzemiosł i Sztuki Stosowanej. Rys historyczny, [w:] W kręgu sztuki przedmiotów. Studia ofiarowane Profesor Irenie Huml przez przyjaciót, kolegów i uczniów, red. M. Dłutek, A. Kostrzyńska-Miłosz, Instytut Sztuki PAN, Warszawa 2011.

Maria Dłutek, Od wzoru do wzornictwa, [w:] Wzornictwo w Polsce, red. M. Kulik, Instytut Wzornictwa Przemysłowego, Warszawa 1987.

Anna M. Drexler, Wystawy wytwórczości Królestwa Polskiego, Oficyna Naukowa, Warszawa 1999.

Alicja Głutkowska-Polniak, Dizajn w kontekście estetyki: jego początki, przeobrażenia i konotacje, Wydawnictwo UŚ, Katowice 2017. 
Irena Huml, Polska sztuka stosowana XX wieku, Wydawnictwa Artystyczne i Filmowe, Warszawa 1978.

Tomasz Mikołajczak, Żaluzjowe meble Władysława Winczego, „Quart” 2017, nr 3. Poznańska zdobnicza: historia Państwowej Szkoły Sztuk Zdobniczych i Przemysłu Artystycznego w Poznaniu w latach 1919-1939, oprac. J. Mulczyński, oprac. graf. M. Pawłowski, ASP w Poznaniu, Poznań 2009.

Stefan Sienicki, Normy w meblarstwie, „Arkady” 1935, nr 2.

Stefan Sienicki, Zagadnienie normalizacji w meblarstwie, [w:] Meble wnętrz mieszkalnych, red. M.J. Leykam, oprac. J. Bogusławki et al., Wydawnictwo Zakładu Architektury Polskiej i Historii Sztuki Politechniki Warszawskiej, Warszawa 1937.

Kinga Szczepkowska-Naliwajek, Dzieje badań nad dawnym rzemiosłem artystycznym w Polsce 1800-1939, Wydawnictwo UMK, Toruń 2005.

Szkoły przemysłowe we Lwowie w XIX i XX w., cz. 1: Miejska Szkoła Przemysłowa i Handlowa, Państwowa Szkoła dla Przemysłu Artystycznego, Państwowa Szkoła Przemysłowa, oprac. J. Kowalczuk, [s. n.], Kraków 2011.

Aldona Tołysz, Muzeum Przemysłu i Rolnictwa w Warszawie. Jedno muzeum - wiele instytucji, http://muzeumpamieci.umk.pl/?p=5077.

Warsztaty Krakowskie 1913-1926, red. I. Dziedzic, Wydawnictwo ASP w Krakowie, Kraków 2009.
Źródła ilustracji
Il. 1. Archiwum autorki.
Il. 2. „Wnętrze” 1933, nr 4, s. 62.
Il. 3-6. Archiwum autorki.
Il. 7. „Projekt” 1960 nr 1/2, s. 10.
Il. 8. Archiwum autorki.

\section{What Is Polish Design?}

The article touches upon the question of the history of Polish industrial design. It analyses its genesis since the second half of the nineteenth century as well as the crucial problem of how 'Polish' and nationally rooted were, in fact, the forms presented by the Polish designers at the time. Further reflections on the topic show two main tendencies - inspirations emerging from 
folk art and the search for modernity (characteristic of the entire European design during the period). Both tendencies are still present in Polish design.

Keywords: Polish design, history of design, Cepelia, The Institute of Industrial Design, Ład, Wanda Telakowska 